\title{
Pengaruh Media Bimbingan dan Konseling Terhadap Motivasi Berprestasi di Kelas Xi SMA N 1 Pariaman
}

\author{
Nadya Silvany ${ }^{1}$, Mori Dianto ${ }^{2}$, Suryadi ${ }^{3}$ \\ STKIP PGRI Sumatera Barat ${ }^{1}$ \\ Email : Nadyasilvany713@gmail.com \\ STKIP PGRI Sumatera Barat ${ }^{2}$ \\ Email : moridianto25@gmail.com \\ STKIP PGRI Sumatera Barat ${ }^{3}$ \\ Email : Suryadies1@gmail.com
}

\begin{abstract}
ABSTRAK
Penelitian ini dilatar belakangi adanya fenomena peserta didik yang memiliki motivasi berprestasi rendah yang cenderung malas dalam belajar, tidak memiliki kemandirian dalam belajar, tidak memiliki perhatian dan konsentrasi dalam belajar, menampakkan minat yang kurang dalam belajar, keengganan mengerjakan tugas, cepat bosan dikelas, berusaha menghindar dari kegiatan belajar, memiliki kecemasan yang tinggi jika dihadapkan dengan tugas yang sulit. Jenis penelitian yang digunakan adalah metode deskriptif kuantitatif.Populasi penelitian ini adalah peserta didik kelas XI SMA N 1 Pariaman.Pengambilan sampel dalam penelitian ini menggunakan teknik proportional random sampling.Dari hasil perhitungan diperoleh sampel sebanyak 120 responden.Instrumen yang digunakan dalam penelitian ini adalah angket.Untuk menganalisis data digunakan rumus regresi linear sederhana guna untuk melihat pengaruh media bimbingan dan Konseling terhadap motivasi berprestasi di kelas XI SMA N 1 Pariaman. Hasil penelitian diperoleh: 1) Gambaran media bimbingan dan konseling berada pada kategori tinggi 2) Gambaran motivasi berprestasi pada kategori sangat tinggi 3) Pengaruh penggunaan media bimbingan dan konseling terhadap motivasi berprestasi berdasarkan uji regresi sebesar 0,382x $100 \%$ atau 38,2\%. Berdasarkan temuan penelitian ini peneliti merekomendasikan kepada peserta didik untuk dapat mempertahankan media bimbingan dan konseling serta meningkatkan motivasi berprestasi.
\end{abstract}

Kata Kunci: Media Bimbingan Dan Konseling, Motivasi Berprestasi

\section{The Effect Of Media Guidance And Counseling On Achievement Motivation In Class Xi SMA N 1 Pariaman}

\begin{abstract}
This research is motivated by the phenomenon of students who have low achievement motivation who tend to be lazy in learning, do not have independence in learning, do not have attention and concentration in learning, show less interest in learning, reluctance to do assignments, get bored quickly in class, try to avoid learning activities, have high anxiety when faced with difficult tasks. The type of research used
\end{abstract}


is descriptive quantitative method. The population of this study were students of class XI SMA N 1 Pariaman. Sampling in this study using proportional random sampling technique. From the calculation results obtained a sample of 120 respondents. The instrument used in this research is a questionnaire. To analyze the data, a simple linear regression formula was used in order to see the effect of guidance and counseling media on achievement motivation in class XI SMA N 1 Pariaman. The results obtained: 1) The description of the guidance and counseling media is in the high category 2) The description of achievement motivation is in the very high category 3) The influence of the use of guidance and counseling media on achievement motivation based on the regression test is $0.382 \times 100 \%$ or $38.2 \%$. Based on the findings of this study, the researcher recommends that students be able to maintain guidance and counseling media and increase achievement motivation.

Keyword: Guidance and Counseling Media, Achievement Motivation

\section{PENDAHULUAN}

Proses penggunaan media menjadi penting karena media memiliki posisi yang strategis bagi keberhasilan dalam memberikan layanan. Alasan utama penggunaan media dalam pelayanan karena didasarkan pada konsep pelayanan sebagai suatu sistem, yang didalamnya terdapat suatu kesatuan yang tersusun dari banyak komponen yang saling berhubungan untuk mencapai tujuan. Media merupakan salah satu komponen utama dalam pelayanan, sudah seharusnya seorang guru menggunakan media dalam pelayanan. Penggunaan media akan meningkatkan hasil belajar yang bermakna sehingga penggunaan media penjadi penting.

Menurut Sanaky, 2005 (Triyono dan Rahmi,2018:75) selaku guru bimbingan dan konseling yang profesional mereka dituntut untuk berwawasan luas serta hal tersebut akan lebih mudah dicapai dengan memenuhi kebutuhan informasi secara cepat serta efisien menggunakan perangkat teknologi informasi. Guru bimbingan dan konseling dapat mencari informasi terbaru yang lagi hangat-hangatnya terjalin serta diaplikasikan dalam wujud media bimbingan dan konseling digital semacam power point, leaflet, booklet, video motivasi dan lain-lain, yang mana hal tersebut bisa mendorong motivasi peserta didik dalam mengikuti kegiatan layanan bimbingan dan konseling. 
Menurut Nursalim, 2013 (Mutmainnah, dkk, 2017:188) media bimbingan dan konseling adalah fasilitas yang bisa digunakan untuk menyalurkan pesan bimbingan dan konseling yang dapat memicupikiran, perasaan, perhatian serta keinginan peserta didik untuk menguasai diri, memusatkan diri, mengambil keputusan serta memecahkan masalah yang dialami. Pemakaianmedia secara kreatif hendak memperbesar kemungkinan peserta didik tertarik pada layanan bimbingan dan konseling, dan untuk belajar lebih banyak, mencamkan apa yang dipelajari lebih baik serta meningkatkan penampilan dalam keahlian sesuai dengan yang menjadi tujuan bimbingan dan konseling.

Menurut Sadiman (Nursalim, 2013:46) guru bimbingan dan konseling memilih media karena beberapa alasan:

1) Demonstration, dalam hal ini hal ini media dapat digunakan sebagai alat untuk menunjukkan konsep, alat objek, cara mengoperasikan dan lain-lain. Beberapa alasan tersebut biasanya menjadi dasar penggunaan media oleh pengguna, yang bertujuan untuk menunjukkan atau memperagakan sesuatu.

2) Familiarity. Penggunaan media bimbingan dan konseling memiliki alasan pribadi dalam menggunakan media yaitu karena sudah terbiasa menggunakan media dan merasa sudah menguasai media tersebut, jika menggunakan media lain belum tentu bisa dan untuk mempelajarinya membutuhkan waktu, tenaga, dan biaya sehingga terus menerus mengguankan media yang sama.

3) Clarity, guru bimbingan dan konseling menggunakan media untuk lebih memperjelas informasi bimbingan dan konseling yang disampaikan serta memberikan penjelasan yang lebih spesifik. Hal ini pula yang menjadi alasan mengapa banyak pengguna media percaya bahwa penggunaan media adalah untuk membuat informasi lebih jelas lebih spesifik dan lebih realisitis.

4) aktifkan siswa/konseli, media bisa lebih dari yang dilakukan guru bimbingan dan konseling. Salah satu aspek yang harus dikejar oleh guru bimbingan dan konseling dalam proses bimbingan dan konseling adalah peserta didik harus berperan aktif secara fisik, mental dan emosional. 
Salah satu faktor yang mempengaruhi prestasi siswa adalah motivasi. Dengan motivasi, siswa akan belajar lebih giat, menjadi lebih rajin serta memiliki konsentrasi dalam proses pembelajaran. Menurut Kompri (2015:03) motivasi dapat diartikan sebagai kekuatan (energi) seseorang yang dapat menimbulkan tingkat persistensi dan antusiasmenya dalam melaksanakan suatu kegiatan, baik yang bersumber dari dalam diri individu itu sendiri (motivasi intrinsik) maupun dari luar individu (motivasi ekstrinsik).

Pada dasarnya motivasi adalah upaya sadar yang bertujuan untuk mengarahkan, membimbing dan memelihara tingkah laku seseorang sehingga memiliki motivasi untuk melakukan sesuatu guna mencapai hasil atau tujuan tertentu. Toding, dkk (2015) motivasi berprestasi diartikan sebagai keinginan untuk mencapai prestasi yang sebesar-besarnya, biasanya ukuran diri sendiri (internal) atau orang lain (eksternal). Motivasi berprestasi merupakan sikap yang mendorong atau membangun untuk mengambil tindakan, menentukan arah dan menambah semangat untuk berprestasi. Motivasi berprestasi seseorang berbeda-beda menurut usianya dan terlihat sejak seseorang berusia lima tahun. Jadi Peserta didik dengan motivasi berprestasi yang baik memiliki ciri-ciri sebagai berikut: peserta didik peka terhadap tantangan (terutama dalam pembelajaran), berpikir rasional, bertanggung jawab dalam keadaan seperti ini selalu bersikap jujur dan semangat dalam belajar, serta berusaha untuk menonjol dalam kelompok. Dan selalu dapat menyesuaikan diri apakah akan berinteraksi dengan-temannya.

Menurut Asnawi (2002:86) ciri-ciri motivasi berprestasi sebagai berikut: 1) mengambil tanggung jawab pribadi atas perbuatannya 2) mencari umpan balik tentang perbuatannya 3) memilih resiko yang sedang dalam perbuatannya 4) berusaha melakukan sesuatu dengan cara-cara baru dan kreatif.

Bedasarkan hasil observasi terhadap peserta didik di kelas XI SMA N 1 Pariaman pada tanggal 19 April 2021 penulis juga mendapatkan informasi bahwasanya peserta didik yang memiliki motivasi rendah cenderung malas dalam belajar, tidak memiliki kemandirian dalam belajar, tidak memiliki perhatian dan konsentrasi dalam belajar, menampakkan minat yang kurang dalam belajar, 
keengganan dalam mengerjakan tugas, cepat bosan berada dikelas, berusaha menghindar dari kegiatan belajar, memiliki kecemasan yang tinggi jika dihadapkan dengan tugas yang sulit.

Berdasarkan hasil wawancara yang telah penulis lakukan pada tanggal19 April 2021 dengan guru bimbingan dan konseling di kelas XI SMA N 1 Pariaman yaitu guru bimbingan dan konseling belum menggunakan media Power Point dan video, guru bimbingan dan konseling belum menggunakan media bagan/chart, grafikdan papan flanel.

\section{METODE PENELITIAN}

Penelitian yang akan penulis lakukan ini adalah penelitian yang bersifat deskriptif kuantitatif. Suryani (2016:109) mengemukakan bahwa penelitian kuantitatif merupakan penelitian yang menggunakan analisis data yang dimana analisis data tersebut berbentuk sebuah angka. Penelitian ini mengggunakan pendekatan deskriptif dengan tujuan untuk mendeskripsikan objek penelitian ataupun hasil penelitian. Adapun pengertian deskriptif menurut sugiyono (2013:29) adalah metode yang berfungsi untuk mendeskripsikan atau memberikan gambaran terhadap objek yang diteliti melalui data atau sampel yang telah terkumpul sebagaimana adanya, tanpa melakukan analisis dan membuat kesimpulan yang berlaku umum.

Jenis data dalam peneltitian ini yaitu data interval langsung, diperoleh dari responden sebagai objek penelitian melalui kuesioner.Populasi penelitian berjumlah 172 peserta didik.Teknik pengambilan sampel proportional random samplingdengan jumlah sampel sebanyak 120 peserta didik.

Menurut Yusuf (2014:163) proportional random sampling merupakan jumlah sampel pada masing-masing strata sebanding dengan jumlah anggota populasi pada masing-masing stratum populasi.

Berdasarkan hasil penelitian yang telah dilakukan tentang pengaruh media bimbingan dan konseling terhadap motivasi berprestasi di kelas XI SMA N 1 Pariaman secara umum terungkap bahwa adanya pengaruh yang signifikan dan positif sebesar $38,2 \%$. 


\section{HASIL DAN PEMBAHASAN}

Hasil penelitian tersebut ditujukan agar melihat pengaruh media bimbingan dan konseling terhadap motivasi berprestasi pada peserta didik di kelas XI SMA Negeri 1 Pariaman.Adapun yang menjadi variabel dalam penelitian ini yaitu media bimbingan dan konseling dan motivasi berprestasi.

\section{Deskripsi Hasil Media Bimbingan Dan Konseling}

Tabel 1. Distribusi Frekuensi dan Kategori Skor Media Bimbingan Dan Konseling pada Peserta Didik Kelas XI di SMA Negeri 1 Pariaman

\begin{tabular}{|c|c|c|c|}
\hline Klasifikasi & Kategori & F & \% \\
\hline$\geq 155$ & Sangat Tinggi & 24 & 20,00 \\
\hline $106-130$ & Tinggi & 72 & 60,00 \\
\hline $81-105$ & Cukup Tinggi & 23 & 19,17 \\
\hline $56-80$ & Rendah & 1 & 0,83 \\
\hline$\leq 55$ & Sangat Rendah & 0 & 0,00 \\
\hline \multicolumn{2}{|c|}{ Jumlah } & 120 & 100,0 \\
\hline
\end{tabular}

Berdasarkan hasil analisis data pada Tabel 1 di atas dapat diketahui gambaran pemilihan menggunakan media bimbingan dan konseling pada peserta didik kelas XI di SMA Negeri 1 Pariaman secara umum, bahwa dari 120 peserta didik, tidak ada seorang pun yang berada pada kategori sangat rendah dengan persentase $(0,00 \%)$, kemudian 1 peserta didik berada pada kategori rendah dengan persentase $(0,83 \%)$, selanjutnya 23 peserta didik berada pada kategori cukup tinggi dengan persentase $(19,17 \%)$, lalu 72 peserta didikberada pada kategori tinggi dengan persentase $(60,00 \%)$, dan 24 peserta didikberada pada kategori sangat tinggi dengan persentase $(20,00 \%)$. Hal ini berarti secara umum media bimbingan dan konseling pada peserta didik kelas XI di SMA Negeri 1 Pariaman berada pada kategori tinggi yakni sebanyak 72 peserta didik dengan persentase $60,00 \%$. 
Berdasarkan pengolahan data tiap indikator maka didapatkan hasil sebagai berikut.

\section{a. Demonstration}

Tabel 2. Distribusi Frekuensi dan Kategori Skor Media Bimbingan Dan Konseling dilihat dari Indikator Demonstration

\begin{tabular}{|c|c|c|c|}
\hline Klasifikasi & Kategori & $\mathbf{f}$ & \% \\
\hline$\geq 45$ & Sangat Tinggi & 43 & 35,83 \\
\hline $30-36$ & Tinggi & 63 & 52,50 \\
\hline $23-29$ & Cukup Tinggi & 13 & 10,83 \\
\hline $16-22$ & Rendah & 1 & 0,83 \\
\hline$\leq 15$ & Sangat Rendah & 0 & 0,00 \\
\hline \multicolumn{2}{|c|}{ Jumlah } & 120 & 100 \\
\hline
\end{tabular}

Dari analisis data pada Tabel 2 tersebut diketahui pemilihan menggunakan media bimbingan dan konseling pada peserta didik kelas XI di SMA Negeri 1 Pariaman dilihat dari indikator demonstration terungkap bahwa dari 120 peserta didik, tidak ada seorang pun yang berada pada kategori sangat rendah dengan persentase $(0,00 \%)$, kemudian 1 peserta didik berada pada kategori rendah dengan persentase $(0,83 \%)$, selanjutnya 13 peserta didik berada pada kategori cukup tinggi dengan persentase $(10,83 \%)$, lalu 63 peserta didik berada pada kategori tinggi dengan persentase $(52,50 \%)$,dan 43 peserta didik berada pada kategori sangat tinggi dengan persentase $(35,83 \%)$. Hal ini berarti demonstration pada peserta didik kelas XI di SMA Negeri 1 Pariaman berada pada kategori tinggi yakni sebanyak 63 peserta didik dengan persentase $52,50 \%$. 


\section{b. Familiarity}

Tabel 3.Distribusi Frekuensi dan Kategori Skor Media Bimbingan Dan Konseling dilihat dari Indikator Familiarity

\begin{tabular}{|c|c|c|c|}
\hline Klasifikasi & Kategori & f & $\%$ \\
\hline$\geq 40$ & Sangat Tinggi & 32 & 26,67 \\
\hline $26-31$ & Tinggi & 67 & 55,83 \\
\hline $20-25$ & Cukup Tinggi & 20 & 16,67 \\
\hline $14-19$ & Rendah & 1 & 0,83 \\
\hline$\leq 13$ & Sangat Rendah & 0 & 0,00 \\
\hline \multicolumn{2}{|c|}{ Jumlah } & 120 & 100 \\
\hline
\end{tabular}

Dari analisis data pada Tabel 3 tersebut diketahui pemilihan menggunakan media bimbingan dan konseling pada peserta didik kelas XI di SMA Negeri 1 Pariaman dilihat dari indikator familiarity terungkap bahwa dari 120 peserta didik, tidak ada seorang pun yang berada pada kategori sangat rendah dengan persentase $(0,00 \%)$, kemudian 1 peserta didik berada pada kategori rendah dengan persentase $(0,83 \%)$, selanjutnya 20peserta didik berada pada kategori cukup tinggi dengan persentase $(16,67 \%)$, lalu 67 peserta didik berada pada kategori tinggi dengan persentase $(55,83 \%)$, dan 32peserta didik berada pada kategori sangat tinggi dengan persentase $(26,67 \%)$. Hal ini berarti familiaritypada peserta didik kelas XI di SMA Negeri 1 Pariaman berada pada kategori tinggi yakni sebanyak 67 peserta didik dengan persentase $55,83 \%$.

\section{c. Clarity}

Tabel 4.Distribusi Frekuensi dan Kategori Skor Media Bimbingan Dan Konseling dilihat dari Indikator Clarity

\begin{tabular}{|c|c|c|c|}
\hline Klasifikasi & Kategori & f & \% \\
\hline$\geq 30$ & Sangat Tinggi & 25 & 20,83 \\
\hline $21-25$ & Tinggi & 71 & 59,17 \\
\hline $16-20$ & Cukup Tinggi & 21 & 17,50 \\
\hline
\end{tabular}




\begin{tabular}{|c|c|c|c|}
\hline Klasifikasi & Kategori & f & \% \\
\hline $11-15$ & Rendah & 3 & 2,50 \\
\hline$\leq 10$ & Sangat Rendah & 0 & 0,00 \\
\hline \multicolumn{2}{|c|}{ Jumlah } & 120 & 100 \\
\hline
\end{tabular}

Dari analisis data pada Tabel 4 tersebut diketahui pemilihan menggunakan media bimbingan dan konseling pada peserta didik kelas XI di SMA Negeri 1 Pariaman dilihat dari indikator clarity terungkap bahwa dari 120 peserta didik, tidak ada seorang pun yang berada pada kategori sangat rendah dengan persentase $(0,00 \%)$, kemudian 3 peserta didik berada pada kategori rendah dengan persentase $(2,50 \%)$, selanjutnya 21peserta didik berada pada kategori cukup tinggi dengan persentase (17,50\%), lalu 71 peserta didik berada pada kategori tinggi dengan persentase $(59,17 \%)$, dan 25 peserta didik berada pada kategori sangat tinggi dengan persentase (20,83\%). Hal ini berarti clarity pada peserta didik kelas XI di SMA Negeri 1 Pariaman berada pada kategori tinggi yakni sebanyak 71 peserta didik dengan persentase $59,17 \%$.

\section{d. Aktifkan siswa/konseli}

Tabel 5.Distribusi Frekuensi dan Kategori Skor Media Bimbingan Dan Konseling dilihat dari Indikator Aktifkan siswa/konseli

\begin{tabular}{|c|c|c|c|}
\hline Klasifikasi & Kategori & F & \% \\
\hline$\geq 40$ & Sangat Tinggi & 48 & 40,00 \\
\hline $26-31$ & Tinggi & 58 & 48,33 \\
\hline $20-25$ & Cukup Tinggi & 13 & 10,83 \\
\hline $14-19$ & Rendah & 1 & 0,83 \\
\hline$\leq 13$ & Sangat Rendah & 0 & 0,00 \\
\hline \multicolumn{2}{|c|}{ Jumlah } & 120 & 100 \\
\hline
\end{tabular}

Dari analisis data pada Tabel 5 tersebut diketahui pemilihan menggunakan media bimbingan dan konseling pada peserta didik kelas XI di SMA Negeri 1 Pariaman dilihat dari indikator aktifkan siswa/konseli terungkap bahwa dari 120 
peserta didik,tidak ada seorang pun yang berada pada kategori sangat rendah dengan persentase $(0,00 \%)$, kemudian 1 peserta didik berada pada kategori rendah dengan persentase $(0,83 \%)$, selanjutnya 13 peserta didik berada pada kategori cukup tinggi dengan persentase $(10,83 \%)$, lalu 58 peserta didik berada pada kategori tinggi dengan persentase $(48,33 \%)$, dan 48 peserta didik berada pada kategori sangat tinggi dengan persentase $(40,00 \%)$.Hal ini berarti aktifkan siswa/konseli pada peserta didik kelas XI di SMA Negeri 1 Pariaman berada pada kategori tinggi yakni sebanyak 58 peserta didik dengan persentase $48,33 \%$.

\section{Deskripsi Hasil Motivasi Berprestasi}

Tabel 6. Distribusi Frekuensi dan Kategori Skor Motivasi Berprestasi pada Peserta Didik Kelas XI di SMA Negeri 1 Pariaman

\begin{tabular}{|c|c|c|c|}
\hline Klasifikasi & Kategori & f & \% \\
\hline$\geq 230$ & Sangat Tinggi & 32 & 26,67 \\
\hline $157-193$ & Tinggi & 74 & 61,67 \\
\hline $120-156$ & Cukup Tinggi & 14 & 11,67 \\
\hline $83-119$ & Rendah & 0 & 0,00 \\
\hline$\leq 82$ & Sangat Rendah & 0 & 0,00 \\
\hline \multicolumn{2}{|c|}{ Jumlah } & 120 & 100,0 \\
\hline
\end{tabular}

Berdasarkan hasil analisis data pada Tabel 12 di atas dapat diketahui gambaran motivasi berprestasi pada peserta didik kelas XI di SMA Negeri 1 Pariaman secara umum, bahwa dari 120 peserta didik, tidak ada peserta didik yang berada pada kategori sangat rendah dengan persentase $(0,00 \%)$, kemudian tidak ada peserta didik yang berada pada kategori rendah dengan persentase $(0,00 \%)$, selanjutnya 14 peserta didik berada pada kategori cukup tinggi dengan persentase $(11,67 \%)$, lalu 74 peserta didik berada pada kategori tinggi dengan persentase $(61,67 \%)$, dan 32 peserta didik berada pada kategori sangat tinggi dengan persentase $(26,67 \%)$. Hal ini berarti secara umum motivasi berprestasi pada peserta didik kelas XI di SMA Negeri 1 Pariaman berada pada kategori tinggi yakni sebanyak 74 peserta didik dengan persentase $61,67 \%$. 
Berdasarkan pengolahan data tiap indikator maka didapatkan hasil sebagai berikut.

\section{a. Mengambil Tanggung Jawab Pribadi Atas Perbuatannya}

Tabel 7.Distribusi Frekuensi dan Kategori Skor Motivasi Berprestasi dilihat dari Indikator Mengambil Tanggung Jawab Pribadi Atas Perbuatannya

\begin{tabular}{|c|c|c|c|}
\hline Klasifikasi & Kategori & F & $\%$ \\
\hline$\geq 65$ & Sangat Tinggi & 54 & 45,00 \\
\hline $43-52$ & Tinggi & 55 & 45,83 \\
\hline $33-42$ & Cukup Tinggi & 10 & 8,33 \\
\hline $23-32$ & Rendah & 1 & 0,83 \\
\hline$\leq 22$ & Sangat Rendah & 0 & 0,00 \\
\hline \multicolumn{2}{|c|}{ Jumlah } & 120 & 100 \\
\hline
\end{tabular}

Dari analisis data pada Tabel 7 tersebut diketahui motivasi berprestasi pada peserta didik kelas XI di SMA Negeri 1 Pariaman dilihat dari indikator mengambil tanggung jawab pribadi atas perbuatannya terungkap bahwa dari 120 peserta didik, tidak ada peserta didik yang berada pada kategori sangat rendah dengan persentase $(0,00 \%)$, kemudian 1 peserta didik berada pada kategori rendah dengan persentase $(0,83 \%)$, selanjutnya 10 peserta didik berada pada kategori cukup tinggi dengan persentase $(8,33 \%)$, lalu 55 peserta didik berada pada kategori tinggi dengan persentase $(45,83 \%)$ dan 54 peserta didik berada pada kategori sangat tinggi dengan persentase $(45,00 \%)$. Hal ini berarti mengambil tanggung jawab pribadi atas perbuatannya pada peserta didik kelas XI di SMA Negeri 1 Pariaman berada pada kategori tinggi yakni sebanyak 55 peserta didik dengan persentase $45,83 \%$. 


\section{b. Mencari Umpan Balik Tentang Perbuatannya}

Tabel 8.Distribusi Frekuensi dan Kategori Skor Motivasi Berprestasi dilihat dari Indikator Mencari Umpan Balik Tentang Perbuatannya

\begin{tabular}{|c|c|c|c|}
\hline Klasifikasi & Kategori & f & \% \\
\hline$\geq 50$ & Sangat Tinggi & 74 & 61,67 \\
\hline $34-41$ & Tinggi & 41 & 34,17 \\
\hline $26-33$ & Cukup Tinggi & 5 & 4,17 \\
\hline $18-25$ & Rendah & 0 & 0,00 \\
\hline$\leq 17$ & Sangat Rendah & 0 & 0,00 \\
\hline \multicolumn{2}{|c|}{ Jumlah } & 120 & 100 \\
\hline
\end{tabular}

Dari analisis data pada Tabel 8 tersebut diketahui motivasi berprestasi pada peserta didik kelas XI di SMA Negeri 1 Pariaman dilihat dari indikator mencari umpan balik tentang perbuatannya terungkap bahwa dari 120 peserta didik, tidak ada peserta didik yang berada pada kategori sangat rendah dengan persentase $(0,00 \%)$, kemudian tidak ada peserta didik yang berada pada kategori rendah dengan persentase $(0,00 \%)$, selanjutnya 5 peserta didik berada pada kategori cukup tinggi dengan persentase $(4,17 \%)$, lalu 41 peserta didik berada pada kategori tinggi dengan persentase $(34,17 \%)$ dan 74 peserta didik berada pada kategori sangat tinggi dengan persentase $(61,67 \%)$. Hal ini berarti mencari umpan balik tentang perbuatannya pada peserta didik kelas XI di SMA Negeri 1 Pariaman berada pada kategori sangat tinggi yakni sebanyak 74 peserta didik dengan persentase $61,67 \%$.

c. Memilih Resiko Yang Sedang Dalam Perbuatannya

Tabel 9.Distribusi Frekuensi dan Kategori Skor Motivasi Berprestasi dilihat dari Indikator Memilih Resiko Yang Sedang Dalam Perbuatannya

\begin{tabular}{|c|c|c|c|}
\hline Klasifikasi & Kategori & f & \% \\
\hline$\geq 55$ & Sangat Tinggi & 10 & 8,33 \\
\hline $38-46$ & Tinggi & 77 & 64,17 \\
\hline $29-37$ & Cukup Tinggi & 33 & 27,50 \\
\hline $20-28$ & Rendah & 0 & 0,00 \\
\hline
\end{tabular}




\begin{tabular}{|c|c|c|c|}
\hline Klasifikasi & Kategori & f & \% \\
\hline$\leq 19$ & Sangat Rendah & 0 & 0,00 \\
\hline \multicolumn{2}{|c|}{ Jumlah } & 120 & 100 \\
\hline
\end{tabular}

Dari analisis data pada Tabel 9 tersebut diketahui motivasi berprestasi pada peserta didik kelas XI di SMA Negeri 1 Pariaman dilihat dari indikator memilih resiko yang sedang dalam perbuatannya terungkap bahwa dari 120 peserta didik, tidak ada peserta didik yang berada pada kategori sangat rendah dengan persentase $(0,00 \%)$, kemudian tidak ada peserta didik yang berada pada kategori rendah dengan persentase $(0,00)$, selanjutnya 33 peserta didik berada pada kategori cukup tinggi dengan persentase $(27,50 \%)$, lalu 77 peserta didik berada pada kategori tinggi dengan persentase $(64,17 \%)$ dan 10 peserta didik berada pada kategori sangat tinggi dengan pesrsentase $(8,33 \%)$. Hal ini berarti memilih resiko yang sedang dalam perbuatannya pada peserta didik kelas XI di SMA Negeri 1 Pariaman berada pada kategori tinggi yakni sebanyak 77 peserta didik dengan persentase $64,17 \%$.

\section{d. Berusaha Melakukan Sesuatu Dengan Cara-cara Baru dan Kreatif}

Tabel 10.Distribusi Frekuensi dan Kategori Skor Motivasi Berprestasi dilihat dari Indikator Berusaha Melakukan Sesuatu Dengan Cara-cara Baru dan Kreatif

\begin{tabular}{|c|c|c|c|}
\hline Klasifikasi & Kategori & f & \% \\
\hline$\geq 60$ & Sangat Tinggi & 33 & 27,50 \\
\hline $42-51$ & Tinggi & 60 & 50,00 \\
\hline $32-41$ & Cukup Tinggi & 24 & 20,00 \\
\hline $42-51$ & Rendah & 3 & 2,50 \\
\hline$\leq 60$ & Sangat Rendah & 0 & 0,00 \\
\hline \multicolumn{2}{|c|}{ Jumlah } & 120 & 100 \\
\hline
\end{tabular}

Dari analisis data pada Tabel 10 tersebut diketahui motivasi berprestasi pada peserta didik kelas XI di SMA Negeri 1 Pariaman dilihat dari indikator berusaha melakukan sesuatu dengan cara-cara baru dan kreatif terungkap bahwa dari 120 
peserta didik, tidak ada peserta didik yang berada pada kategori sangat rendah dengan persentase $(0,00 \%)$, kemudian 3 peserta didik yang berada pada kategori rendah dengan persentase $(20,00 \%)$, selanjutnya 24 peserta didik berada pada kategori cukup tinggi dengan persentase $(20,00 \%)$, lalu 60 peserta didik berada pada kategori tinggi dengan persentase $(50,00 \%)$ dan 33 peserta didik berada pada kategori sangat tinggi tinggi dengan persentase $(27,50 \%)$. Hal ini berarti berusaha melakukan sesuatu dengan cara-cara baru dan kreatif pada peserta didik kelas XI di SMA Negeri 1 Pariaman berada pada kategori tinggi yakni sebanyak 60 peserta didik dengan persentase $50,00 \%$.

\section{KESIMPULAN}

Berdasarkan hasil penelitian tentang pengaruhmedia bimbingan dan konseling terhadap motivasi berprestasi di kelas XI SMA Negeri 1 Pariaman dapat diambil kesimpulan sebagai berikut.

1. Pemilihan menggunakan media bimbingan dan konseling pada peserta didik di kelas XI SMA Negeri 1 Pariamanberada pada kategori tinggi.

2. Motivasi berprestasi peserta didik di kelas XI SMA Negeri 1 Pariaman berada pada kategori tinggi.

3. Terdapat pengaruh yang signifikan dan positif pemilihan menggunakan media bimbingan dan konseling terhadap motivasi berprestasi di kelas XI SMA Negeri 1 Pariaman

\section{DAFTAR PUSTAKA}

Asnawi, S. 2002. Teori Motivasi. Jakarta: Studio Press.

Kompri. 2015. Motivasi Pembelajaran Perspektif Guru Dan Siswa. Bandung: Remaja Rosdakarya.

Mutmainnah, Aqidha Nurul, Dkk. 2017. Media Bimbingan Konseling Berbasis Hypermedia. Penerapan Operasional Penyelenggaraan (POP) Bimbingan Dan Konseling Di Sekolah Dalam Menyikapi Tantangan Profesi BK Di Abad 21.

Nursalim, Mochamad. 2013. Pengembangan Media Bimbingan Dan Konseling. Jakarta Barat: Indeks. 
Sugiyono. 2013. Metode Penelitian Manajemen. Bandung: Alfabeta.

Suryani dan Hendryadi. 2016. Metode Riset Kuantitatif: Teori dan Aplikasi Pada Penelitian Bidang Manajemen dan Ekonomi Islam. Jakarta: Prenadamedia Group.

Toding, Wastie R. B, Dkk. 2015. Hubungan Dukungan Sosial Dengan Motivasi Berprestasi Pada Mahasiswa Angkatan 2013 Fakultas Kedokteran Universitas SAM Ratulangi. Jurnal E-Biomedik (Ebm). Vol. 3, No. 1.

Triyono, Dan Rahmi Dwi Febriani. 2018. Pentingnya Pemanfaatan Teknologi Informasi Oleh Guru Bimbingan Dan Konseling. JUANG: Jurnal Wahana Konseling. Vol. 1, No, 2.

Yusuf, Muri. 2014. Metode Penelitian: Kuantitatif, Kualitatif Dan Penelitian Gabungan. Jakarta: Kencana. 